\title{
Jogpolitika
}

HRECSKA-KovÁcs RenÁTA-KovÁcs BÁLINT-CSIRSZKI MARTIN*

\section{Megoldási alternatívák a koronavírus-járvány által előidézett szociális jogi problémákra (nemzetközi kitekintés)}

\author{
Alternative Solutions to the Problems Posed by the Coronavirus Pandemic \\ in the Field of Social Law (An International Outlook)
}

\begin{abstract}
ABSZTRAKT
A 2020-as koronavírus-járvány olyan politikai, gazdasági és társadalmi válaszlépéseket kényszerít ki a világ nemzeteinek vezetőiből, amelyekre sok esetben nem volt korábban példa. Kiváló, új koncepciók születtek a megfelelö szakemberek munkája révén, ugyanakkor voltak kezdeményezések, amelyekröl már rövidtávon bebizonyosodott, hogy nem kellöen megalapozottak. Jelen tanulmány célja, hogy a válság hatására kialakult gyakorlatokat, megoldási alternatívákat felvillantsa, abból kiindulva, hogy a jövőre nézve ez az év sok tanulsággal szolgálhat a döntéshozók számára.
\end{abstract}

Kulcsszavak: koronavírus, válság, foglalkoztatás elősegítése, vállalkozások fennmaradási lehetőségei, családtámogatás

\begin{abstract}
The 2020 coronavirus pandemic is forcing such political, economic and social responses from the leaders of the nations of the world which in many cases have never been seen before. Excellent new concepts have been formed through the work of professionals, and there have been initiatives that have proven in the short term to be not well-founded. The present study was created in order not to miss the chance to examine the established practices, taking advantage of the opportunity provided by the crisis, as this year can offer many lessons for decision-makers for the future.
\end{abstract}

Keywords: coronavirus, crisis, employment promotion, business survival, family support

* Dr. Hrecska-Kovács Renáta, kutató, Mádl Ferenc Összehasonlító Jogi Intézet, Magánjogi Kutatási Főosztály, Budapest; e-mail: renata.hrecska@mfi.gov.hu. Kovács Bálint, kutató, Mádl Ferenc Összehasonlító Jogi Intézet, Magánjogi Kutatási Főosztály, Budapest; e-mail: balint.kovacs@mfi.gov.hu. Dr. Csirszki Martin, kutató, Mádl Ferenc Összehasonlító Jogi Intézet, Magánjogi Kutatási Főosztály, Budapest; e-mail: martin.csirszki@ mfi.gov.hu. 
Súlyos egészségügyi válság sújtja a világot, amelynek gazdasági és társadalmi következményei is érezhetővé váltak az egészségügyi biztonsági intézkedések eredményeként. A politikai vezetők, korábbi tapasztalat hiányában, egyénileg próbálják a járvány miatti negatív hatásokat kezelni és megelőzni. $A$ járvány a legtöbb államban, noha eltérő súlyossággal jelentkezett, folyamatosan terjed, ennek következtében megnőtt az egészségügyre fordított kiadások kezelésének fontossága. Az egészségügyi helyzet stabilizálásának érdekében elrendelt szociális távolságtartásnak súlyos gazdasági következményei vannak, és várhatóan hasonló jelenségekkel kell számolnunk a közeljövőben is. A munkavégzésre, az oktatásra, valamint a családi helyzetre lesújtó hatással bíró szociális távolságtartás következményeire a kormányok válasza ezidáig föként a lakosság anyagi segélyezésében merült ki. A szociális katasztrófa megelőzését - vagy inkább enyhítését - célzó intézkedések közé, a válságidőszakokban jellemző módon, számos kreatív megoldás is került, amelyek a helyzet okozta hátrányos társadalmi folyamatokat jövedelem-kiegészítéssel, munkaszüneti napokkal vagy egyébként pénzben meghatározott segélyekkel próbálják enyhíteni.

Mára egyértelművé vált, hogy a pandémia hatásait még néhány évig érezni fogjuk, viszont az újfajta koronavírus járvány „első hullámára” adott kormányzati reakcióként a biztonsági és segélyezési intézkedéseket csak ideiglenesen és rövid időre vezették be, fenntartva a meghosszabbítás lehetőségét. A koronavírus-járvány kapcsán megfigyelésünk, hogy bizonyos rendelkezéstípusokat minden államban vagy az államok többségében alkalmaztak, így e körben általánosan beszélünk döntéshozókról; míg néhol külön említünk államokat, ahol olyan specialitással találkoztunk, amelyröl érdemesnek tartjuk külön megemlékezni.

Az intézkedések feltételrendszere és sok esetben az ideiglenes jellege, illetöleg a járványkezelési intézkedések bürokráciája miatt felmerülő nehézségek a kedvezményezettek türelmét is kikezdték, ráadásul az elektronikus kommunikációra való hirtelen áttérés is sokakat felkészületlenül ért. Feszültségforrás emellett, hogy olyan államokban, ahol az elektronikus ügyintézés, ügyletkötés nem mindennapi bevett gyakorlat, elektronikus aláirás hiányában az államoknak egyéb kompromisszumos megoldásokat kellett találniuk a kérelmek befogadására. Nyilvánvaló, hogy az állam célja nem lehet más, mint a sajátos társadalmi helyzet hatékony kezelése, és egy esetleges szociális katasztrófa elkerülése. A jogszabályi intézkedések sok esetben hasonlóak, viszont minden állam a saját nemzeti problémáira keresett megoldást, ami kirajzolódik az általunk elemzett gyakorlatok bemutatása során is. Jelen tanulmányban a járvány által kiváltott különleges helyzetre tekintettel elfogadott szociális, segélyezési és családtámogatási, valamint néhány, az üzleti szférát érintő intézkedést mutatunk be. Az intézkedésekröl elsősorban a nemzeti jogszabályokból és kormányzati forrásokból tájékozódtunk, de nem volt célunk ezeket teljességében elemezni. E tanulmány a lényegesebb, egyrészt gyakrabban megjelenő (például a csökkentett munka), másrészt pedig az inkább „unortodox” (például a feltétel nélküli alapjövedelemhez hasonló) intézkedések áttekintését szolgálja. 


\section{Intézkedések a foglalkoztatás elősegítése érdekében}

Az államok a foglalkoztatás elősegítésének területén az egyes intézkedésekkel arra törekszenek, hogy a jelenlegi járványügyi helyzetben a foglalkoztatás szintjének fenntartását biztosítsák. Ennek keretében általában átfogó jellegű, a munkaerőpiacot hatékonyan, ámde jobbára rövid távon szinten tartó intézkedéseket vezetettek be. Egyes országok azonban ahelyett, hogy átcsoportosították volna a forrásokat, és új, innovatív megoldásokon dolgoztak volna, a meglévő lehetőségekböl emeltek ki egy-egy jogintézményt, megerősítve ezen eszközök foglalkoztatási jelentőségét.

Mindkét megközelítés indokolt lehet, hiszen a források átcsoportosítása révén kétségtelenül azonnali segítségnyújtásra kerülhetett sor azon vállalkozások számára, amelyek a válság hatására nem tudták volna fenntartani a munkavállalói állományukat; így egy gazdasági mélyzuhanásba torkolló spirálba avatkozott be az állami foglalkoztatáspolitika. Egyidejüleg a második megközelítés létjogosultsága mellett is érvelhetünk, hiszen az annak jegyében bevezetett intézkedések nem vontak el további erőforrásokat a kormányzati szervektől, emellett a társadalom tagjaitól is kisebb alkalmazkodást vártak el, és gyorsan végrehajthatók voltak.

Fontosnak látjuk megemlíteni, hogy például Spanyolországban egyedi, dogmatikailag is figyelemre méltó megoldás született, amikor a kormányzat megállapította, ${ }^{1}$ hogy a COVID-19 következményeként bekövetkezett tevékenységvesztés vis maiornak minősül a szerződések felfüggesztése, a munkaidő csökkentése, illetve az ezekre irányuló eljárások szempontjából.

\subsection{Szinten tartó támogatások a munkáltatók és munkavállalók számára}

A bevezetőben bemutatott, két állami beavatkozási modell körében elsőként azokat a megoldásokat nézzük meg, amelyek nagyobb volumenű pénzügyi segítséget jelentettek a munkáltatók és/vagy a munkavállalók számára. Az egyik legfontosabb és legjellemzőbb ide tartozó jogintézmény a német és az osztrák jog által alkalmazott Kurzarbeit, azaz csökkentett vagy rövidített munkavégzés. ${ }^{2}$ Németország ${ }^{3}$ már korábban is ismerte és alkalmazta ezt a lehetőséget, ${ }^{4}$ amelyet Magyarország kifejezetten a koronavírus-járvány gazdasági nehézségeinek enyhítése érdekében

\footnotetext{
1 2020/8. törvényerejü rendelet II. fejezet 22-24. cikk. (Real Decreto-ley 8/2020, de 17 de marzo de medidas urgentes extraordinarias para hacer frente al impacto económico y social del COVID-19.) https://boe.es/ buscar/act.php?id=BOE-A-2020-3580 (2020. 03. 21.).

${ }^{2}$ Az ILO kimutatása szerint az elvesztett munkaórák száma rosszabb arányokat mutat, mint az előzetesen becsülhető volt. Ennek következményeként növekszik a munkavállalói inaktivitás, ami a szakpolitika egyik komoly kihívása ebben az időszakban. ILO Monitor: COVID-19 and the world of work. Sixth edition Updated estimates and analysis, 23. September 2020. https://www.ilo.org/wcmsp5/groups/public/@dgreports/@dcomm/ documents/briefingnote/wcms_755910.pdf (2020. 11. 09.).

${ }^{3}$ Németország intézkedéseinek részletes bemutatására lásd KRAUSE, Rüdiger-KüHN, Jonas Walter: COVID-19 and Labour Law: Germany. Italian Labour Law e-Journal, Covid-19 and Labour Law. A Global Review. Special Issue 1, 2020.

$126{ }^{4}$ A szabályokat a Kurzarbeitergeldre vonatkozóan Németországban a Sozialgesetzbuch III 95-106. §§-ai tartalmazzák.
} 
vett át. A jogintézmény nem tekinthető klasszikus munkanélküli segélynek, de nem is fogható fel kizárólag a munkáltatónak adott támogatásként, hanem sokkal inkább hibrid eszköz, amelyből a munkaviszony mindkét oldalán álló szereplők profitálnak, ezért az egyik leghatékonyabb eszköznek tekinthető a foglalkoztatás elősegítése területén. ${ }^{5}$

Gazdasági kényszerhelyzetben a munkáltató ultima ratio-ként a munkavállalók elbocsátására kényszerülhet, amely döntés - számos esetben - nem rendelkezik valós alternatívával. A Kurzarbeitergeld ezt az alternatívát teremti meg, hiszen egyfajta segélyként funkcionál a munkavállalók és a munkáltatók számára egyaránt, mégpedig havonkénti járadék formájában. A munkáltatónak nem kell elbocsátania a munkavállalóját, pusztán csökkenti annak munkaidejét, viszont a csökkentett munkaidő a munkavállaló oldalán nem jár arányos munkabércsökkentéssel, hiszen az eredeti és a csökkentett munkaidő különbözetére járó munkabér egy részét az állam magára vállalja. A koronavírus miatti veszélyhelyzet kihirdetésére tekintettel például Ausztriában az eredetileg 20 millió eurónyi Kurzarbeit-támogatásokra fordítható öszszeget felemelték 400 millió euróra 2020. szeptember 30-ig. ${ }^{6}$

A Kurzarbeit-támogatások igénybevételének, gyakorlatilag minden államban, ahol elérhető ez a lehetőség, az a feltételrendszere, hogy a munkáltató valamilyen gazdasági kényszerhelyzetre tekintettel csökkenteni kényszerül azon munkaórák számát, amelyekre a müködése fenntartásához szüksége van (tipikusan a kevesebb megrendelés miatt), s ennek következményeként a munkaidő csökkentését is végre kell hajtania. Ennek tényét a hatáskörrel rendelkezö munkaügyi hivatalnak be kell jelentenie - Ausztriában az igénybevételhez többletfeltétel még, hogy a munkaügyi hivatal és a munkáltató közötti egyeztetés során más megoldást ne találjanak a felek a nehézségek orvoslására. Bizonyos részletszabályok ezekhez képest is felmerülhetnek: Németországban például ahhoz, hogy a munkáltató a Kurzarbeit-ot elrendelhesse, előzetesen annak lehetőségét kollektív szerződésben vagy a munkavállaló egyéni munkaszerződésében kell rögzíteni. ${ }^{7}$ Ezzel jellegében megegyezik Ausztria szabályrendszere, amely szerint harmadik feltételként a munkáltatónak és a munkavállalóknak egyezségre kell jutnia a Kurzarbeit-ot illetően. ${ }^{8}$

A koronavírus-járvány jelentős munkacsökkenést eredményezett a vállalkozások nagy többségének működésében, ami a német szabályozásban akként jelenik meg, hogy „idölegesen és elkerülhetetlenül, gazdasági tényezökön ${ }^{9}$ vagy elháríthatatlan események miatt a naptári évben normál esetben a munkavállalók legalább egy-

\footnotetext{
${ }^{5}$ Arról, hogy Magyarországon miként tudott megvalósulni egy ehhez a rendszerhez hasonló bértámogatási struktúra, lásd BERKE Gyula: Munkajog veszélyhelyzetben. In: Pál Lajos-Petrovics Zoltán: Visegrád 17.0, A XVII. Magyar Munkajogi Konferencia szerkesztett előadásai. Wolters Kluwer, Budapest, 2020, 29.; KÁRTYÁs Gábor: A munkaidő szabályok veszélyhelyzet idején Megvéd vagy gúzsba köt? Magyar Munkajog efolyóirat, 2020/1., 51-53.

${ }^{6}$ COVID-19-Gesetz, Artikel 5.

${ }^{7}$ Koch, Ulrich: Kurzarbeit (szócikk). In: Schaub, Günther-Koch, Ulrich (Hg.): Arbeitsrecht von A-Z. C.H. Beck, 24. Auflage, München, 2020.

${ }^{8}$ Arbeitsmarktservicegesetz, 37a. § (1).

${ }^{9}$ Azaz, ha a munkáltató például azért mond vissza munkákat, mert eleve kapacitáshiány volt nála, ez nem kielégítő feltétel.
} 
harmadának, a koronavírus-járvány kapcsán legalább 10\%-ának, ${ }^{10}$ havi bruttó jövedelme minimum 10\%-kal csökken (amely csökkenés akár 100\%-ig is terjedhet)." A támogatás igénybevételének feltétele továbbá, hogy a munkáltatónál legalább egy munkavállaló alkalmazásban álljon, ${ }^{11}$ a támogatás folyósításának feltétele, hogy a foglalkoztatottak munkaviszonyát nem szüntetheti meg a munkáltató. ${ }^{12}$

Megítélésünk szerint fontos körülmény, hogy a koronavírus-járvány okozta gazdasági elnehezülés ellensúlyozása végett Kurzarbeitergeld-re a munkaerö-kölcsönzés keretében foglalkoztatott munkavállalók is jogosulttá váltak, azaz a munkaerőkölcsönzéssel foglalkozó vállalatok is bejelenthetik a munkaügyi hivatalnak a munkacsökkenést. ${ }^{13}$

Németország a pénzügyi segítségnyújtás mellett intelligens tervezéssel arra ösztönzi a munkavállalókat, hogy akinek az eredeti munkaviszonyában munkacsökkenés miatt a munkaideje (és ezzel párhuzamosan a munkabére) is csökkent, a felszabadult idejében a rendszerszinten fontos ágazatokban és foglalkozásokban vállaljon munkát. Ennek eszközeként (a Sozialgesetzbuch - a továbbiakban: SGB - III 421c. § alapján) aki 2020. december 31-ig ilyen munkát vállal, annak az SGB III 106. § (3) bekezdésétő/ ${ }^{14}$ eltérően az ez után kapott jövedelme nem adódik hozzá a tényleges jövedelemhez a Kurzarbeitergeld folyósítása alatt. További feltétel még, hogy a két munkaviszony után kapott jövedelem együttes összege nem haladhatja meg a Kurzarbeitergeld alapját képező munkaviszony teljes jövedelmét. ${ }^{15}$

A jogintézmény ezidáig sikeresnek bizonyult a gyakorlatban. Ezt támasztja alá az is, hogy Magyarország, illetve további államok szintén bevezettek a Kurzarbeitgeldhez (Ausztriában Kurzarbeithilféhez) hasonló konstrukciókat. A romániai munka törvénykönyve 52. szakasza lehetővé teszi a gazdasági, technológiai, strukturális vagy hasonló okokból történő ideiglenes munkaidő csökkenés vagy munkavégzési szünet elrendelését, mely esetben a járványügyi intézkedések alapján a munkáltatók a munkaszerződések hatályát ideiglenesen felfüggeszthetik. Ilyen esetekben a munkavállaló nem végezhet munkát, a munkáltató bérezésre vonatkozó kötelezettségét pedig az állam veszi át. A pandémia által előidézett intézkedések szerint az állam az érintett munkavállalók részére a munkabérük 75\%-ának, de legfeljebb az országos átlagbér $75 \%$-ának megfelelő támogatást biztosít. Lényegében az állam

${ }^{10}$ Gesetz zur befristeten krisenbedingten Verbesserung der Regelungen für das Kurzarbeitergeld vom 13. März 2020, Artikel 1.

11 SGB III, 97. §.

12 SGB III, 98. § (1) 2 .

${ }^{13}$ A szövetségi munkaügyi és szociális tárca sajtóközleménye, 2020. 03. 16. https://www.bmas.de/DE/Presse/ Meldungen/2020/mit-kurzarbeit-gemeinsam-beschaeftigung-sichern.html (2020. 09. 18.).

${ }^{14}$ Ez a jogszabályhely állapítja meg, hogy a Kurzarbeitergeld folyósítása alatt, ha a Kurzarbeitergeld alapját képező munkaviszonytól eltérő másik munkaviszonyból a munkavállaló munkabért kap a munkacsökkenés következtében felszabadult idejében végzett munka után, akkor ez utóbbi munkabérét hozzá kell számítani a Kurzarbeitergeld alapját képező munkaviszonyából származó munkabéréhez. Ezt oldja fel az új rendelkezés a rendszerszinten fontos ágazatokban és foglalkozásokban végzett „másodállás” vonatkozásában. Ilyennek számít, például az egészségügy, a közlekedés, a telekommunikáció, az energiaszektor stb. Lásd a Nordstadtblogger összeállítását, 2020. 03. 17. https://www.nordstadtblogger.de/corona-diese-branchen-undberufe-gelten-als-systemrelevant-und-fuer-sie-gibt-es-kinderbetreuung/ (2020. 12. 14.).

15 Sozialschutz-Paket, Artikel 2, 2. 
ilyen módon szeretné biztosítani a munkaviszonyok fenntartását a pandémia alatt. A munkáltatók az érvényes munkaszerződések 75\%-ában élhetnek ezzel a támogatási lehetőséggel. ${ }^{16}$

Szlovákiában ${ }^{17}$ is láthatunk törekvést a kormányzat részéröl arra, hogy a munkahelyek megőrzése érdekében támogatást nyújtson. A munkáltatókat két csoportba sorolták, eszerint megkülönböztették azokat, akik bezártak és álláshelyeiket fenntartották, ${ }^{18}$ valamint azokat, akik nem zártak be, de legalább $20 \%$-kal csökkent a forgalmuk, és az álláshelyeiket fenntartották. Itt is visszaköszön a német rendszerböl megismert feltétel, amely szerint a munkavállalók jogviszonyát a támogatásért folyamodó munkáltató nem szüntetheti meg. Amennyiben ez mégis megtörténik, a munkáltatók egyéb gazdasági támogatásért folyamodhatnak a müködésük szerinti állam vállalkozásösztönző rendelkezései szerint. A járványidőszak speciális mentőcsomagjait azonban nem vehetik igénybe, hiszen azoknak minden államban az a célja, hogy a nehéz helyzetbe került munkáltatókat és munkavállalókat segítsék a munkaeröpiaci egyensúly megörzése érdekében.

Csehországban a csökkentett munkavégzés lehetősége helyett egy alternatív jogintézménnyel, a részleges munkanélküliséggel kezdődtek a járványügyi intézkedések. ${ }^{19}$ Eszerint ha csökken a kereslet a termék vagy az igény a szolgáltatás iránt, a munkáltató csökkentett bérkompenzációt fizethet a munkavállalói részére, amely nem lehet kevesebb, mint az átlagbér $60 \%$-a. Ennek a munkáltató általi bevezetése nem történhet meg egyik pillanatról a másikra, elötte egyeztetni szükséges a szakszervezettel (ha van), illetve előzetesen be kell jelenteni, hogy mit jelent a részleges munkanélküliség, és az pontosan milyen hatással lesz ez a bérekre. ${ }^{20} \mathrm{Ez}$ a jogintézmény azonban a részmunkaidős foglalkoztatáshoz képest nem előnyös a munkavállalók számára, ezért a nagyobb mértékủ visszaesés esetén érdemes inkább utóbbit választania a munkáltatónak. Arra is oda kell figyelnie a munkáltatónak, hogy számára a legköltségesebb megoldás, ha a helyzetet az ő oldalán felmerült, egyéb akadálynak minősítik, mert ez esetben a munkavállaló teljes bérét ki kell fizetni. ${ }^{21}$ Ez leginkább akkor merülhet fel, ha a munkáltató maga dönt úgy, hogy - bár a járványügyi megszorító intézkedések rá nem vonatkoznak - de elővigyázatosságból bezárja az üzemét, és a munkavállalók nem tudják a munkájukat otthonról elvégezni. ${ }^{22}$

A visszásságok miatt a munkahelyek megörzése érdekében a cseh állam a Kurzarbeit mintájára intézkedéscsomagot dolgozott ki, így 100 milliárd cseh korona

\footnotetext{
${ }^{16}$ 30/2020. sz. sürgősségi kormányrendelet a SARS-CoV-2 koronavírus terjedése által okozott járványügyi helyzettel összefüggésben egyes jogszabályok módosításáról és kiegészítéséről, valamint a szociális védelem területén hozandó intézkedések meghatározásáról.

${ }^{17}$ A szlovák kormányzat intézkedéseiről lásd részletesen: KRIŽAN, Viktor: COVID-19 and Labour Law: Slovakia. Italian Labour Law e-Journal, Covid-19 and Labour Law. A Global Review. Special Issue, 2020/1.

${ }^{18} \mathrm{Az}$ első csoport számára minden munkavállaló után jár bérkompenzáció (az átlagbér 80\%-áig, legfeljebb 1100 euróig), a második csoportban a támogatás mértéke sávosan változik.

${ }^{19}$ Csehország munka törvénykönyve 209. §.

${ }^{20}$ Cvinerová, Barbora-Karas, Ladislav-Szutányi, Romana: How government restrictions on business affect employee relations. KPMG Tax and Legal Update, 2020. 03. 18. https://danovky.cz/en/how-governmentrestrictions-on-business-affect-employee-relations (letöltés ideje: 2020. 09. 18.).

${ }^{21}$ Csehország munka törvénykönyve 208. §.

${ }^{22}$ Cvinerová-Karas-Szutányi: i. m.
} 
közvetlen támogatást és 900 milliárd cseh korona közvetett támogatást nyújtott a vállalkozásoknak garancia formájában. A kormány a munkáltatókon keresztül kifizette a karanténnal érintett munkavállalók bérének $60 \%$-át. Emellett a cseh állam támogatta a munkáltatókat, akik annak ellenére, hogy üzletüket be kellett zárni, továbbra is kifizették az érintett munkavállalóik munkabérének 100\%-át, esetükben a bérköltségek $80 \%$-át átvállalta az állam. ${ }^{23}$

Svájcban ${ }^{24}$ mindemellett arra is láthatunk példát, hogy a kormányzat az egyszerüsített foglalkoztatásnak nevezett, rövidebb időtartamú jogviszonyban alkalmazottak helyzetét is megpróbálta segíteni. Így azok is részesülhettek a munkaóra-csökkentés kedvezményében, akiknek az úgynevezett fluktuációs rátája meghaladja a $20 \%$-ot, de legalább hat hónapja ugyanazon foglalkoztatónál állnak alkalmazásban. Svájcban körülbelül 200000 egyszerüsített foglalkoztatásban dolgozó munkavállaló van, akik könnyen aránytalanul kiszolgáltatottá válhattak volna ezen intézkedések hiányában. Az intézkedéscsomag hatására az egyszerüsített foglalkoztatás keretében alkalmazottak is élhettek a munkaóra-csökkenés esetén biztosított keresetpótlás lehetöségével. ${ }^{25}$

Az Egyesült Királyság egyfelöl (short-time work support néven) biztosítja a támogatást azon munkavállalók számára, akiknek a munkaidejét csökkenteni kellett. ${ }^{26}$ Ugyanakkor - bár az elnevezés jellegében hasonlít a Kurzarbeitra - ebben a rendszerben nem annyira a foglalkoztatás elösegítéséről, mint inkább az amerikai rendszerhez hasonló, bérpótló intézkedésekröl beszélünk. A munkavállaló kérheti az elbocsátását, és igényelheti az elbocsátással járó kompenzációt, ha akár az úgynevezett lay-off, ${ }^{27}$ akár a short-time working ${ }^{28}$ négy egymást követö héten, vagy egy tizenhárom hetes perióduson belül hat héten keresztül tart. A lay-off és a short-time ${ }^{29}$ időszak alatt a munkavállalónak meg kell kapnia a teljes fizetését, kivéve, ha a munkaszerződés lehetővé teszi a fizetetlen vagy a csökkentett fizetéssel járó távollétet. A short-time work support-on felül az angol kormány is vezetett be munkahely-megtartó intézkedéscsomagot (the Government's Coronavirus Job Retention Scheme), ${ }^{30}$ amelynek keretében gyakorlatilag ugyanazokat biztosítják, mint a német rendszert alkalmazó államok. ${ }^{31}$

${ }^{23}$ Measures adopted by the Czech Government against the coronavirus. A Cseh Kormány honlapja, https:// www.vlada.cz/en/media-centrum/aktualne/measures-adopted-by-the-czech-government-against-coronavirus-180545/ (2020. 12. 14.).

${ }^{24}$ A Svájcban irányadó intézkedéscsomagról lásd részletesen: PÄRLI, Kurt: COVID-19 and Labour Law: Switzerland. Italian Labour Law e-Journal, Covid-19 and Labour Law. A Global Review. Special Issue 1, 2020.

${ }^{25}$ Coronavirus: adaptations en matière de chômage partiel et scénarios pour la conjoncture suisse. A Svájci Szövetségi Tanács honlapja, 2020. 04. 08. https://www.admin.ch/gov/fr/accueil/documentation/communiques/communiques-conseil-federal.msg-id-78742.html (2020. 21. 14.).

${ }^{26}$ Az Egyesült Királyság kormányzati portálja: https://www.gov.uk/lay-offs-short-timeworking (2020. 09. 18.)

${ }^{27}$ A fogalom azt jelenti, hogy a munkavállalónak legalább egy napja nincs munkája - például, ha a kormányzat utasította a munkáltatót bezárásra (jellemzően mozik, vendéglátóhelyek, színházak stb. esetén).

${ }^{28}$ A fogalom azt jelenti, hogy a munkavállaló munkaidejét csökkentik.

${ }^{29} \mathrm{Az}$ információk forrása az Egyesült Királyság kormányzati portálja. https://www.gov.uk/lay-offs-short-timeworking (2020. 09. 18.).

${ }^{30}$ Az Egyesült Királyság kormányzati portálja. https://www.gov.uk/government/news/coronavirus-job-retentionscheme-up-and-running (2020. 09. 18.).

31 Április 20-án életbe léptették a kormány úgynevezett munkahely-megtartó rendszerét, amelyen keresztül a vállalkozások online havi 2500 fontot igényelhetnek az alkalmazottaik béreire. A pénzbeli támogatások a bé- 
Az Amerikai Egyesült Államokban bonyolult támogatási rendszer alakult ki. Központilag, az erre elkülönített keretböl anyagi támogatást biztosítottak azoknak a szövetségi államoknak, amelyek osztott munkaidő programokat (work-sharing program) hoztak létre. A jogintézmény célja ugyanaz, mint amit a Kurzarbeit esetében láttunk. Ahelyett, hogy teljesen megszüntetnék a munkaviszonyt, ösztönzik az alkalmazottak munkaidejének csökkentését, egy részleges munkanélküli segély fizetésével kiegészítve az alkalmazottak jövedelmét. ${ }^{32}$

2020 első negyedévében a becslések szerint a globális munkaidő 5,6 százaléka veszett el a munkaidő-csökkentések és a bezárások révén, ami 160 millió teljes munkaidős állással egyenértékü. ${ }^{33}$ Mindez felértékeli a Kurzarbeit jellegủ jogintézmények jelentőségét, hiszen az ilyen megoldások nélkül a mutatók még súlyosabb képet adnának.

\subsection{A munkaviszony megszüntetésének elkerülése érdekében alkalmazott megoldások}

Az állam által nyújtott pénzbeli segítség kétségtelenül a leghatékonyabb olyan megoldásnak tủnik, amely a munkáltatók és a munkavállalók számára egyaránt kézzel fogható biztonságot ad. Ugyanakkor a véges kormányzati költségvetés miatt ezek nem alkalmazhatóak korlátok nélkül; szükség van kiegészítő vagy alternatív megoldások megteremtésére, hiszen mind a feltételrendszerben, mind idöben behatárolt a pénzügyi segítség folyósítása.

Az ILO 2020 őszén kiadott összefoglaló jelentése szerint a világ összes munkavállalójának 94\%-a érintett valamilyen munkahely-bezárással. ${ }^{34}$ Ennek fényében azt látjuk, hogy a különböző segélyeket, pályázatokat, kifizetési könnyítéseket kiegészíti, sőt inkább megelőzi az a jelenség, hogy a munkaviszonyokat, ahol csak a munkavégzés természetéből adódóan lehetőség nyílt erre, távmunkavégzés keretében rendelték el a munkáltatók. ${ }^{35}$ Jelen alfejezet néhány szóban ezt az intézkedéscsomag-típust kívánja bemutatni. Bővebben e helyütt nem értekezünk a távmunkavégzés és a home office lehetőségeiről és hátrányairól, ugyanakkor említést kell tenni róla, mert a járvánnyal kapcsolatban kialakult munkaügyi helyzetet megkerülhetetlenül jellemzi az atipikus foglalkoztatási formák megerősödése.

Sok helyen a munkavégzés távoli/otthoni munkavégzésként való megszervezése újdonságnak számított, ám általános tapasztalat, hogy több vállalat a járványidőszak első nagy hullámának lecsengése után is megtartotta ezt a formát. Ennek oka,

rek akár $80 \%$-át is meghaladhatják. A munkáltatók részére a támogatás összegét általában hat munkanapon belül utalják át.

${ }^{32}$ United States: Short Time Compensation (Work Share) Programs - Are They Right for You? A Baker\& McKenzie áttekintése, 2020. 04. 21. https://www.bakermckenzie.com/en/insight/publications/2020/04/unitedstates-short-time-compensation-programs (2020. 12. 14.).

33 ILO monitor, i. m., 4.

34 ILO Monitor, i. m., 1.

${ }^{35}$ Franciaországban például köztársasági elnöki rendeletben rendelték el a távmunkavégzést 2020. március 17-én. Les mesures prises par le Gouvernement, 2020. 09. 18. https://www.gouvernement.fr/info-coronavirus (2020. 12. 14.). Szlovákiában a foglalkoztatásért felelős minisztérium kérte fel a távmunkavégzés elrendelésére a munkáltatókat. 
hogy a cégek számára is előnyökkel jár a távmunkavégzés, még inkább a home office lehetőségének megteremtése, hiszen például nem kell fenntartani irodahelyiséget, vagy csökkenteni lehet a takarítási, adminisztrációs, ellátási stb. költségeket.

Távmunkavégzés hiányában a munkavállalónak nem sok lehetősége volt és van arra, hogy a munkába járást elkerülje: egyfelöl igénybe veheti a még fel nem használt szabadságát, kedvezöbb esetben pedig a munkáltató dönthet úgy is, hogy megváltoztatja a munkavégzés munkarendjét, esetlegesen munkavégzés hiányában állásidőre járó távolléti díjat fizet ${ }^{36}$ - ez azonban a munkáltató számára súlyos többletköltséggel járhat, amely akár a munkaviszony fenntartását is ellehetetlenítheti. Önkéntes karantén esetén a munkavállaló és a munkáltató megállapodhatnak arról, hogy a távollétet igazoltnak tekintik vagy sem, illetve, hogy ez időre jár-e a munkavállalónak bérkompenzáció. ${ }^{37}$

Ez a helyzet fennállt és fennáll gyakorlatilag mindenhol: amennyiben a távmunkavégzés/home office lehetőségével a munkáltató nem tud, vagy nem kíván élni, a munkáltató szabadságot adhat ki a munkavállaló számára. A munka törvénykönyve a munkáltató számára biztosítja a szabadság kiadásának jogát az ott meghatározott mértékben, így még ha a munkavállaló esetleg nem is szeretné kivenni a szabadságot, a munkáltató kiadhatja számára saját belátása szerint. A veszélyhelyzeti rendelkezésekre tekintettel az az alapelv is kevésbé érvényesülhet, hogy nem okozhat aránytalan sérelmet a munkavállalónak a szabadság kiadásának megtervezésével, hiszen álláspontunk szerint a szükségesség és arányosság mércéje is amellett hat, hogy a munkavállaló maradjon távol a munkavégzés helyétől. Csehországban a kormányzati intézkedések következtében még az alól is felmentést kaptak a munkáltatók, hogy 14 nappal korábban tájékoztassák beosztottjaikat a szabadságolás tényéröl, bár viszonylagos garanciát jelent, hogy amennyiben egy vállalat tömegesen küldi szabadságra a foglalkoztatottakat, akkor ehhez a szakszervezet hozzájárulása is szükséges. ${ }^{38}$ Olaszországban ezzel szemben az úgynevezett okos munka (lavoro agile) keretében, ahol az lehetséges, fizetett szabadság és munkanélküli segély használatát irányozták elő minden szakterületen, az alkalmazottak számától függetlenül. Lényeges kikötés volt az olasz kormányzat részéröl emellett egy felmondási korlátozás bevezetése, amelynek értelmében korlátozás nélkül csak fegyelmi jelleggel volt megszüntethető a munkaviszony, illetve a határozott idejű szerződések lejáratát leszámítva, az egyéb okra alapozott felmondás lehetősége felfüggesztésre került. ${ }^{39}$

\footnotetext{
${ }^{36}$ A távmunkavégzés és az állásidő koronavírus-járvánnyal kapcsolatos összefüggéseiröl lásd bővebben BERKE: i. m., 34-35.; GYULAVÁRI Tamás: Vészhelyzet a munkajogban: Szerződési szabadság és munkáltatói hatalom. Fundamentum, 2020/1, 75-84. Az állásidőre járó díjazás szempontjából különösen fontos a vis maior gyakorlati alkalmazási lehetőségeinek vizsgálata, amely kérdésről lásd bővebben Boóc Ádám: Megjegyzések a COVID-19 vírus hatásairól a magyar szerződési jogban, különös figyelemmel a vis maior fogalmára. Glossa luridica, különszám: Jog és Vírus. 2020, 85-94.

${ }^{37}$ Magyarországon általánosan fellazultak a munkajogi kötöttségek a járvány apropóján meghozott törvényhozói intézkedéseknek köszönhetően. Erröl lásd bővebben GYULAVÁRI már idézett cikkén kívül Kun Attila: Munkajogi elvi kérdések: a felek (munkáltató és munkavállaló) egyéni megállapodásainak mozgásteréröl. Glossa luridica, különszám: Jog és Vírus, 2020, 145-156.

${ }^{38}$ Cvinerová-Karas-Szutányi: i. m.

${ }^{39} \mathrm{Az}$ olaszországi 2020. évi 18. számú törvényrendelet szerint, annak hatályba lépésétől számított 60 napig a munkáltató nem bocsáthatta el objektív (szervezeti és gazdasági) okok miatt az alkalmazottait, illetve a február 23-án megkezdett elbocsátásokat felfüggesztette 60 napig (46. cikk).
} 
Tényleges karantén esetében (amilyennek akár egy teljes üzemleállás is minősülhet) ezzel szemben nem a szabadság szabályai érvényesülnek, hanem a munkavállalók ugyanolyan bérkompenzációra jogosultak, mint betegség idején: tehát az első 14 napon átlagbérük $60 \%$-ának megfelelö összegre jogosultak, melyet a munkáltató fizet, a 15. naptól kezdve pedig a társadalombiztosítás által biztosított táppénz alkalmazására kerül sor.

\subsection{A munkavállalók támogatása a munkahely elvesztése esetén}

A munkahelyek megtartására irányuló szándék természetszerüleg nem minden esetben ér el eredményt, így az államok újragondolták a munkanélküliség esetén elérhető munkáltatói és munkavállalói támogatások rendszerét is. Az egyes intézkedések elsősorban arra koncentrálnak, hogy a szolgálati idő és a társadalombiztosítási ellátások folytonossága biztosított legyen. Ide kapcsolódó munkáltatói támogatás például a munkáltatók járulékfizetési kötelezettségének felfüggesztése, amiről a vállalkozások támogatásáról szóló részben írunk részletesebben. Emellett azonban közvetlenül a munkavállalót is érintheti hasonló kedvezmény: Spanyolországban például a fizetési halasztásra nézve állapítottak meg könnyített szabályokat. ${ }^{40}$

A mediterrán ország fontos intézkedése továbbá, hogy könnyítette a munkanélküli támogatáshoz való hozzáférés szabályait, mely szerint minden, a munkáltató által próbaidő alatt közölt, 2020. március 9-e utáni felmondást úgy kell tekinteni, hogy az a munkavállalóra nézve államilag elismert munkanélküli státuszt eredményez, függetlenül attól, hogy a munkanélküli támogatáshoz szükséges szolgálati idővel rendelkezik-e a munkavállaló. Hasonló a szabály azon munkavállalók esetében is, akiknek 2020. március 1. után úgy szünt meg felmondással a jogviszonya, hogy a leendő munkáltatójuk elállt a szerződéstöl a járvány okozta válság miatt, és így a munkavállaló elhelyezkedése meghiúsult. ${ }^{41}$

\subsection{Egyéb támogatási formák}

Néhány ország nem új intézkedéseket irányzott elő a koronavírus-járvány negatív hatásának mérséklése céljából, hanem a meglévő jogintézmények igénybevételi lehetőségét egyszerüsítette. Példaként hozhatjuk Svájcot, ahol bizonyos kiemelten érintett szektorokban (például gyógyszeripar, gyógyászattal kapcsolatos területek, földművelés, logisztika) a munkaerő-toborzás egyszerüsítése érdekében az álláshelyek meghirdetésével kapcsolatos munkáltatói és foglalkoztatási szervezeti kötelezettségek szünetelnek. ${ }^{42}$

\footnotetext{
${ }^{40}$ A 2020/8. törvényerejü rendelet angol nyelvű kivonata. elérhető: https://www.garrigues.com/sites/default/ files/documents/covid19_royal_decree_82020_0.pdf; 2020.09. 18.). https://www.mfcr.cz/cs/aktualne/tiskovezpravy/2020/vlada-schvalila-moratorium-na-splatky-uv-38077 (2020. 09. 18.)

${ }^{41}$ A spanyol törvényhozás koronavírus-járvánnyal kapcsolatos intézkedései a következő weboldalon érhetőek el: https://boe.es/biblioteca_juridica/codigos/codigo.php?id=355\&modo=2\&nota=0\&tab=2

42 A Svájci Szövetségi Tanács sajtóközleménye, 2020. 03. 25. https://www.admin.ch/gov/fr/accueil/documentation/communiques.msg-id-78573.html (2020. 09. 18.).
} 
Hasonlóan a munkavégzés folyamatosságát segítő, egyszerűsítő jogalkotói döntésként tekintünk Lengyelország ${ }^{43}$ azon intézkedésére, amelynek keretében felfüggesztésre kerültek ${ }^{44}$ a munka törvénykönyvének és a vasúti, illetve közúti közlekedésröl szóló törvénynek a kötelező munkaköri alkalmassági vizsgálatokra vonatkozó egyes szabályai. A koronavírus-járvány ideje alatt a munkáltató mentesült a kötelező időszakos munkaköri alkalmassági ellenőrzés biztosítása alól. A felfüggesztés nem vonatkozik a soron kívüli és a munkába lépést megelőző munkaköri alkalmassági vizsgálatokra, azonban - az eddigi szabálytól eltérően - az ilyen alkalmassági vizsgálatokat olyan orvos is elvégezheti, aki különben nem jogosult a munkaköri alkalmassági ellenőrzésre. Az orvosi igazolások és a munkavállalási engedélyek érvényességi idejét szintén meghosszabbították. ${ }^{45}$

\section{A vállalkozások, egyéni vállalkozók tevékenységének fenntartásához kapcsolódó támogatási formák}

A vállalkozások és egyéni vállalkozók támogatási csomagjának jelentős részét a vizsgált országok mindegyikében különböző járulék- és adófizetési könnyítések, közüzemi díffizetéssel kapcsolatos halasztások, illetöleg hitelfelvétellel kapcsolatos egyszerüsítés vagy hiteltörlesztési moratórium bevezetése teszi ki. Általános gyakorlatként jelent meg az állami intézkedések részeként, hogy a végrehajtási eljárásokat és intézkedéseket, a bankszámlák zárolását vagy a késedelmi dijjak felszámolását is felfüggesztették azon jogi személyek esetében, amelyek érintettek voltak a járványügyi intézkedések következményei által. ${ }^{46} \mathrm{~A}$ támogatások közötti eligazodásban jellemzően a különböző közigazgatási hivatalok segíthettek és segítenek a vállalkozásoknak. Ezen szabályok áttekintésekor kivételként találkoztunk az Egyesült Királyság ${ }^{47}$ szabályozásával, amely kreatívabb megoldást biztosított a vállalkozások és az egyéni vállalkozók számára az úgynevezett üzleti támogatások kereső rendszere (business support finder tool) ${ }^{48}$ révén. Egy online platformon keresztül egyszerüen megtudható, hogy az érintettek milyen támogatást tudnak igénybe venni a koronavírus-járvány idején. A vállalkozások tulajdonosainak egy néhány percet igénybe vevő online kérdőívet kell kitölteniük, és a rendszer listázza a számukra hozzáférhető pénzügyi támogatásokat.

${ }^{43}$ Lengyelország tekintetében lásd részletesen FLORCZAK, Izabela: COVID-19 and Labour Law: Poland. Italian Labour Law e-Journal, Covid-19 and Labour Law. A Global Review. Special Issue 1, 2020.

${ }^{44}$ A módosított koronavírus-törvény $12 a$. cikke.

${ }^{45}$ A módosított koronavírus-törvény 15zzq. cikke.

${ }^{46}$ Lásd például Németország esetében: Ein Schutzschild für Beschäftigte und Unternehmen. Maßnahmenpaket zur Abfederung der Auswirkungen des Corona-Virus. Bundesministerium der Finanzen, Bundesministerium für Wirtschaft und Energie, 2020. 03. 13., 3. Elérhető a Szövetségi Pénzügyminisztérium honlapján, a sajtóközlemények között: https://www.bundesfinanzministerium.de/Content/DE/Pressemitteilungen/Finanzpolitik/2020/03/2020-03-13-download-de.pdf (2020. 03. 19.).

${ }^{47}$ Az Egyesült Királyság kormányzatának intézkedéscsomagjáról lásd NovITz, Tonia: COVID-19 and Labour Law: United Kingdom. Italian Labour Law e-Journal, Covid-19 and Labour Law. A Global Review. Special Issue 1, 2020.

${ }^{48}$ A brit kormány sajtóközleménye, 2020. 04. 20. https://www.gov.uk/government/news/government-launchesnew-coronavirus-business-support-finder-tool (2020. 09. 18.). 
Természetesen a kifizetésekkel összefüggő halasztások mellett tényleges pénzügyi segítséget is igényelhettek a vállalkozások sok államban. Németországban például három hónapon keresztül havi 9.000 eurót kaptak a legfeljebb öt munkavállalót foglalkoztató vállalkozások, valamint 15.000 eurót a legfeljebb 10 munkavállalót foglalkoztatók. ${ }^{49}$ Emellett Ausztriában ${ }^{50}$ az úgynevezett második covid-törvény szerint a szövetségi fejlesztési és finanszírozási bank, valamint az osztrák turizmusfejlesztési és finanszírozási bank által normál körülmények között biztosítható 750 millió euróig, valamint 375 millió euróig terjedő kis- és középvállalkozásoknak nyújtandó garanciavállaló támogatás ${ }^{51}$ mértékét az osztrák pénzügyminiszter rendeleti úton három hónapos időtartamra felemelhette..$^{52}$

Franciaország 2020. március 3-án hozta létre a Gazdasági Minisztérium irányítása alatt a gazdasági folytonosság fenntartásáért felelős egységet. Különleges kezdeményezés az üzleti mediáció program (Médateur des enterprises), amelytől a kormány azt várta, hogy a cégeknek az ügyfelekkel és a beszállítókkal való kapcsolata javulhat, a járvány okozta átmeneti időszakot könnyebben átvészelhetik az üzleti kapcsolatok fennmaradása esetén. ${ }^{53}$

További előremutató kezdeményezést találtunk Szlovákia intézkedéscsomagjának elemzésekor. Szlovákiában kibővítették a munkaügyért felelős minisztérium humanitárius alapját, és létrehozták az úgynevezett S. O. S. juttatást. ${ }^{54} \mathrm{Ez}$ azon emberek számára nyújthat segítséget, akik valamilyen oknál fogva egyik olyan, általános támogatási kategóriába sem tartoznak, amelyben a koronavírus-járvány negatív gazdasági hatásait kívánták ellensúlyozni.

Több országhoz hasonlóan Svájc olyan szabályozást vezetett be, mellyel expressis verbis engedélyt adott arra, hogy a hatályban lévő munkaügyi szabályoktól meghatározott jogalanyok eltérjenek. A kórházak, klinikák jelen helyzetben betöltött kiemelt szerepére való tekintettel elismerték a döntéshozók, hogy a túlterhelés és a szakemberek korlátozott száma miatt lehetetlen elvárni a munkaügyi szabályok maradéktalan betartását. Ennek fényében számukra engedélyezett volt, hogy a lehető legteljesebb mértékben eltérhessenek a munkaidő-pihenőidő szabályaitól. Hasonló megoldással élt Lengyelország, hiszen a koronavírus-törvény szerint a bevételcsökkenést produkáló munkáltatóknál a napi pihenőidő időtartamát legfeljebb 8 óráig lehetett csökkenteni (11 óra helyett), a heti pihenőidő időtartama pedig 32 óránál

${ }^{49}$ Corona-Hilfen sollen besonders verwundbaren Gruppen schnell helfen. Lásd: Spiegel Wirtschaft, 21. 03. 2020. https://www.spiegel.de/wirtschaft/soziales/coronavirus-staatshilfe-fuer-hartz-iv-privatschuldner-soloselbstae ndige-a-37e8f2ce-3f88-4702-b08a-f711c4fc2395 (2020. 03. 21.).

${ }^{50}$ Ausztria tekintetében lásd RISAK, Martin: COVID-19 and Labour Law: Austria. Italian Labour Law e-Journal, Covid-19 and Labour Law. A Global Review. Special Issue 1, 2020.

51 A garanciavállaló támogatás lényege az, hogy a két állami tulajdonú pénzintézet az említett összeghatárokig kezességet, illetve garanciát vállal a kis- és középvállalkozások által felvett kölcsönökért és hitelekért, így egyszerübben juthatnak e jogalanyok kölcsönhöz és hitelhez, hiszen a kis- és középvállalkozás mögött az állam áll kezesként vagy garanciavállalóként.

52 2. COVID-19-Gesetz, Artikel 2, 4.

${ }^{53}$ Confinement: chômage partiel ou travail? Quelles conditions? Quelles nouvelles mesures? Quelles démarches? MaCommune.info, Édition Besançon, 23/03/2020. https://www.macommune.info/confinement-chomage-partiel-ou-travail-quelles-conditions-quelles-nouvelles-mesures-quelles-demarches/ (2020. 03. 25.).

${ }^{54}$ A szlovák munkaügyi, szociális és családügyi minisztérium honlapja. https://www.employment.gov.sk/sk/ministerstvo/poskytovanie-dotacii/archiv/2020/sos-dotacie.html (2020. 09. 18.). 
nem lehetett rövidebb (35 óra helyett). A munkafeltételek megváltoztatása a teljes napi munkaidő meghosszabbítására is kiterjedhetett, ebben az esetben a teljes napi munkaidőt 12 óráig lehetett meghosszabbítani a legfeljebb 12 hónapos elszámolási időszakban. ${ }^{55}$

\section{Családi támogatások}

A családokat is erőteljesen sújtotta a vírus terjedése, föleg olyan esetekben, amikor a nevelési-oktatási intézmények - a bölcsődék, óvodák és iskolák - bezárását rendelték el a hatóságok. Az otthon maradt gyerekek felügyeletét a szülöknek kellett megoldaniuk, ami a rendes, de még az otthoni munkavégzés kapcsán is kihívást jelent.

A helyzet enyhítésére Németországban a munkaügyi miniszter informális kéréssel fordult a munkáltatókhoz, hogy a gyermekfelügyeleti problémákkal küzdő munkavállalókkal kompromisszumos, és amennyiben lehet, bürokráciamentes megoldást találjanak. Arra kérte őket, hogy minimum egy hétig engedélyezzék a gyermekfelügyeletet a munkabér csökkentése nélkül. Másrészről, a munkavállalóktól is hasonló rugalmasságot kért; akár fizetett munkaszüneti napjaikat is használják fel arra, hogy a gyerekeikre vigyázzanak. ${ }^{56}$ Ezzel a kéréssel az internet által is megkönnyített otthoni, vagy távmunka típusú munkavégzési lehetőségek maximális kiaknázását, valamint a pénzügyi stabilitás megörzését ösztönözte a kormány.

A májusban megjelent szociális védelmi csomag (Sozialschutz-Paket) a családok támogatásához akként járult hozzá, hogy kedvezőbb feltételeket állapított meg a gyermekek után igényelhető segély (az úgynevezett Kinderzuschlag) vonatkozásában. Átmenetileg kizárólag az igénylési kérelem benyújtását megelöző hónap jövedelmét vették figyelembe, illetve felfüggesztették a vagyonvizsgálatot annak érdekében, hogy az ellátás könnyebben hozzáférhető, az eljárás pedig minél kevésbé bürokratikus legyen. ${ }^{57} \mathrm{~A}$ segély ugyanakkor azon munkavállalók kisegítésére is irányult, akik a nevelési-oktatási intézmények bezárása, és ennek következtében a 12. életévét be nem töltött gyermekük felügyelete miatt munkát nem tudtak végezni, s így munkabérük csökkent. Ennek feltétele volt, hogy más módon a gyermekfelügyeletet nem tudták megoldani, ${ }^{58}$ valamint más jogszerü lehetőség a munkától való távolmaradásra nem állt fenn. Ekkor legfeljebb hat hétig a nettó jövedelem $67 \%$-át, de legfeljebb 2.016 eurót biztosított az állam, mégpedig olyan formában, hogy az összeg kifizetését a munkáltató megelölegezte, $s$ az év végéig az e jogcímen kifizetett összeget visszaigényelhette a hatáskörrel rendelkező állami szervtől. E szabály

\footnotetext{
${ }^{55}$ A módosított koronavírus-törvény 15zf. cikke. A teljes napi munkaidő meghosszabbítása és a kedvezőtlenebb munkafeltételek alkalmazása kizárólag a szakszervezettel vagy a munkavállalói képviselettel kötött szerződés alapján valósulhat meg, olyan munkáltatónál, akinek nincs adó- vagy járuléktartozása 2019 harmadik negyedévével bezárólag.

${ }^{56}$ Lohnfortzahlung bei Kinderbetreuung. A szövetségi munkaügyi és szociális tárca közleménye, 2020. 03. 15. https://www.bmas.de/DE/Presse/Meldungen/2020/lohnfortzahlung-bei-kinderbetreuung.html (2020. 03. 19.).

57 Sozialschutz-Pakete. A szövetségi munkaügyi és szociális tárca közleménye, 2020. 05. 28. https://www.bmas. de/DE/Schwerpunkte/Informationen-Corona/Sozialschutz-Paket/sozialschutz-paket.html (2020. 09. 19.).

${ }^{58}$ A nagyszülők általi gyermekfelügyelet a rendelkezés szerint sem alternatíva az idősebb korosztály fokozott veszélyeztetettsége miatt.
} 
nem volt alkalmazható, s így a támogatás nem volt vehető igénybe oktatási szünet ideje alatt. ${ }^{59}$

Ausztriában a jogszabályok elöírták, hogy a köznevelési-közoktatási intézmények bezárásától számított három héten át speciális gyermekfelügyeleti időt biztosíthatott a munkáltató annak a munkavállalónak, akinek gyermeke a 14. életévét nem töltötte be. Ebben az esetben a munkáltató jogosult volt a gyermekfelügyeleti idő alatt fizetett munkabér egyharmadának állam általi megtérítésére. ${ }^{60}$

Franciaországban a távoktatás megkezdésével a rászoruló gyerekek (a családok kb. 5\%-a) számára elektronikus eszközöket biztosított az állam a helyi igazgatáson keresztül, a távoktatási platformok kihasználása érdekében. Ehhez társult egy gyermekfelügyeleti rendszer is, annak érdekében, hogy a járvány okozta krízismenedzsmentben érintett munkavállalók (tehát föképp egészségügyi dolgozók) 16. életévét be nem töltött gyermekei ne maradjanak megfelelő támogatás nélkül. Az oktatási minisztérium és a helyi igazgatás irányítása alatt áló szakembereket szintén március 16-tól mozgósították, hogy 8-10 fős foglalkozásokat tarthassanak az érintett gyermekek számára. ${ }^{61}$

Szlovákiában, amennyiben iskolabezárás miatt merült fel a gyermekgondozás szükségessége, legfeljebb tíz éves gyermekek esetében gondozási dij volt igényelhető az illetékes társadalombiztosítási hivatalnál. A gondozási díj mindaddig járt a szülőnek, ameddig az iskolák és óvodák zárva tartottak. Ez a tizenegy évnél fiatalabb gyermekek szüleinek járt, illetve a súlyos fogyatékossággal élő gyermek esetében a korhatár a tizennyolc életévben került megállapításra. Ezen életkori korlátok között nem volt szükség orvosi igazolásra (hiszen a gyermek valójában nem azért maradt otthon, mert beteg). A gyermekgondozási díj a bruttó bér $55 \%$-a, amely a nettó bér 70\%-a volt. További újításként jelent meg, hogy a szülök felváltva is igénybe vehették a támogatást. ${ }^{62}$

Csehországban a tizennegyedik életévüket be nem töltött gyermekek esetében volt igényelhető hasonló gyermekgondozási járadék a nevelési-oktatási intézmények bezárásának ideje alatt. ${ }^{63}$ További intézkedések kerültek elfogadásra a kisgyermeket nevelő vállalkozók esetében, akik legfeljebb egy havi 13.144 cseh koronából álló támogatást igényelhettek. A cseh kormány gondolt azokra az egyéni vállalkozókra is, akik nem tudtak munkát végezni, mert otthon kellett maradniuk a gyermekkel. Az állam napi 424 cseh koronát biztosított azon egyéni vállalkozók számára, akik 6-13 éves gyermekről gondoskodtak, de csak abban az esetben, ha a másik szülő nem jogosult gyermekgondozási díjra. ${ }^{64}$

\footnotetext{
${ }^{59}$ A szövetségi munkaügyi és szociális tárca idézett közleménye, 2020. 05. 28.

60 COVID-19-Gesetz, Artikel 7.

${ }^{61}$ Les mesures prises par le Gouvernement Pour la scolarité de vos enfants; Fermeture de tous les établissements scolaires. Lásd a francia kormány tájékoztató oldalát, https://www.gouvernement.fr/info-coronavirus (2020. 03. 20.).

62 Prvá sociálna pomoc v čase pandémie. A szlovák szaktárca közleménye, 2020. 03. 25. https://www.employment. gov.sk/sk/informacie-media/aktuality/prva-socialna-pomoc-case-pandemie.html (2020. 12. 04.).

${ }^{63}$ A cseh szociális tárca sajtóközleménye, 2020. 03. 19. https://www.mpsv.cz/documents/20142/1248138/19_03 +TZ+ošetřovné+AKTUÁLNĚ.pdf/aab4c8c3-8e88-ca8a-708f-1a1436e92944 (2020. 03. 22.).

${ }^{64}$ A cseh kormány sajtóközleménye, 2020. 03. 20. https://www.vlada.cz/en/media-centrum/aktualne/government-approves-proposal-to-extend-the-payment-of-care-allowance-during-the-state-of-emergency-the-selfemployed-will-also-receive-money-180504 (2020. 03. 22.).
} 
Az Egyesült Királyságban az ingyenes iskolai étkezésre jogosult gyerekek az iskolák zárva tartásának ideje alatt hetente 15 font értékben online felületen keresztül kaptak olyan étkezési utalványokat, amelyeket szupermarketekben lehetett levásárolni. ${ }^{65}$

Spanyolországban a COVID-19 gazdasági hatásának kezelésére szolgáló, rendkívül sürgős intézkedésekröl szóló törvényerejű rendelet ${ }^{66}$ II. fejezete a családok védelme érdekében támogatási intézkedéseket tartalmaz. Ennek értelmében azok a családok, akiknek a gyermekei évközben étkezési támogatást kaptak, pénzügyi támogatásra vagy élelmiszerosztásra voltak jogosultak (8. cikk). ${ }^{67}$

Hollandiában a kormányzat és az önkormányzatok egyebek mellett gyermekgondozást is biztosítottak az iskolákban és a gyermekgondozási központokban a kulcsfontosságú ágazatokban dolgozók gyermekeinek, hogy ezek a szülők továbbra is el tudják látni feladataikat. A kulcsfontosságú ágazatokat az egészségügy, a tömegközlekedés, a rendőrség és a tűzoltóság, valamint egyéb fontos ágazatokban jelölték meg. ${ }^{68}$

Romániában a nevelési-oktatási intézmények zárva tartásának idejére az egyik szülő számára fizetett munkaszüneti napokat ajánlottak fel a közoktatási intézmények átmeneti bezárása esetén, a gyermekeiket gondozó szülők szabadnapokban való részesítéséröl szóló 19/2020. számú törvény rendelkezéseinek végrehajtásáról szóló 217/2020. sz. kormányhatározat alapján. A jogszabály szerint abban az esetben kérelmezhette az egyik szülő a fizetett szabadnapokat, amennyiben olyan munkakörben dolgozik, amely nem látható el otthoni munkavégzéssel, illetve, ha az iskolás gyermek tizenkét évnél fiatalabb. ${ }^{69}$ Fogyatékkal élő gyermek esetében a korhatár 18 év volt. A fizetett szabadnap az egyik szülőt illette meg, aki erre az időszakra a fizetésének $75 \%$-ára volt jogosult. A fizetés összege semmi esetre sem haladhatta meg a bruttó nemzeti átlagbér $75 \%$-át. ${ }^{70} \mathrm{Az}$ állam - kérelem alapján - a munkáltató által kifizetett munkaszüneti napokat hatvan napon belül térítette meg. ${ }^{71}$

Lengyelországban a távmunkavégzés elősegítésével próbálták a gyermekgondozás kérdését megoldani, ${ }^{72}$ ehhez hozzátéve egy gyermekgondozási díjat, amit legfel-

${ }^{65} \mathrm{~A}$ brit kormány sajtóközleménye, 2020. 03. 31. https://www.gov.uk/government/news/voucher-schemelaunches-for-schools-providing-free-school-meals (2020. 04. 05.).

${ }^{66}$ 2020/8. törvényerejű rendelet.

${ }^{67}$ 2020/7. törvényerejü rendelet. (Real Decreto-ley 7/2020, de 12 de marzo, por el que se adoptan medidas urgentes para responder al impacto económico del COVID-19.) https://boe.es/buscar/doc.php?id=BOEA-2020-3580 (2020. 03. 21.).

${ }^{68}$ COVID-19: Additional measures in schools, the hospitality sector and sport. A holland kormányzati portál hírei, 2020. 03. 15. https://www.government.nl/latest/news/2020/03/15/additional-measures-in-schools-thehospitality-sector-and-sport (2020. 12. 04.)

${ }^{69}$ A gyermekeiket gondozó szülők szabadnapokban való részesítéséről szóló 19/2020. számú törvény 1. szakaszának 2. bekezdése.

${ }^{70}$ A gyermekeiket gondozó szülők szabadnapokban való részesítéséröl szóló 19/2020. számú törvény rendelkezéseinek végrehajtásáról szóló 217/2020. sz. kormányhatározat 2. szakasza.

71 217/2020. sz. kormányhatározat 3. szakasz 5 . bekezdés.

72 Ustawa z dnia 2 marca 2020 r. o szczególnych rozwiązaniach związanych z zapobieganiem, przeciwdziałaniem i zwalczaniem COVID-19, innych chorób zakaźnych oraz wywołanych nimi sytuacji kryzysowych, Dz.U. z 2020 r. poz. 374, a módosított koronavírus-törvény 3. cikke. 
jebb 14 napra kérelmezhettek a jogosult szülök, nyolc év alatti gyermek esetében. ${ }^{73}$ A fogyatékkal élő gyermek esetén a kiegészítő gyermekgondozási díj a gyermek 18. életévének betöltéséig járt. A 14 napos periódust később többször meghosszabbították. ${ }^{74} \mathrm{~A}$ kiegészítő gyermekgondozási díj a munkabér $80 \%$-ával volt egyenlö. A koronavírus-törvényben bevezetett kiegészítő gyermekgondozási díj nem érintette a rendes gyermekgondozási díjra vonatkozó jogosultságot, amelynek időtartama 60 nap lehet évenként. A szülők vagy gondozók igénybe vehették a kiegészítő gondozási dijat a fogyatékkal élő felnőtt személy otthoni gondozása céljából is, abban az esetben, ha a rehabilitációs intézmény bezárása miatt a munkavégzés alól mentesültek.

Olaszországban a 16 éven aluliak után (a fogyatékossággal élők esetében pedig korhatártól függetlenül) 15 fizetés nélküli munkaszüneti nap járt a szülök bármelyikének, a törvény vagy munkaszerződés által elöírt munkaszüneti napokon felül. Továbbá, az állam biztosította egy egyszeri, legfeljebb 600 (rendőrségi és egészségügyi dolgozóknál legfeljebb 1.000) euró összegủ családi pótlék folyósítását bébiszitterszolgáltatás igénybevétele esetére. A rendkívüli munkaszüneti napok után a munkavállaló jogosult volt fizetésének $50 \%$-ára, amennyiben az igénylő szülő gyermeke nem haladta meg a 12. életévet. Azok az örökbefogadó szülök, akik súlyos fogyatékossággal élő gyermeket nevelnek, további munkaszüneti napokra voltak jogosultak.

A kínai vezetés különös figyelmet fordított a járvány hatásai miatt aktív szülői felügyelet nélkül maradt gyermekek védelmére. ${ }^{75}$ Erre vonatkozóan 2020. március 14-én tett közzé egy tervet a kormányzat, ${ }^{76}$ amelynek értelmében az érintett gyermekekröl való gondoskodást a gyermek lakóhelye szerinti illetékes helyi kormányszervnek kellett megszerveznie. ${ }^{77} \mathrm{Az}$ iskoláskorú gyermekek számára a szülöi felügyelet nélkülözése esetén az iskolának és a gyermekjóléti szolgálatoknak kellett gondoskodniuk arról, hogy az oktatás biztosított legyen az érintett gyermek részére. ${ }^{78}$

Az USA-ban könnyítéseket vezettek be a gyermekgondozás céljából való otthonmaradásra, és minden gyermek után, aki 16 éves vagy annál fiatalabb, a szülők 500 dollárt kaptak. Ezt a segélyt olyanok kaphatták meg, akik az adóbevallásukat benyújtották.

\footnotetext{
${ }^{73}$ A módosított koronavírus-törvény 4. cikke.

${ }^{74}$ Rozporządzenie Rady Ministrów z dnia 10 kwietnia 2020 r. w sprawie określenia dłuższego okresu pobierania zasiłku opiekuńczego w celu przeciwdziałania COVID-19 (Dz.U. z 2020 r., poz. 656), rozporządzenie Rady Ministrów z dnia 24 kwietnia 2020 r. w sprawie określenia dłuższego okresu pobierania zasiłku opiekuńczego w celu przeciwdziałania COVID-19 (Dz.U. z 2020 r., poz. 748) i i rozporządzenie Rady Ministrów z dnia 30 kwietnia 2020 r. w sprawie określenia dłuższego okresu pobierania zasiłku opiekuńczego w celu przeciwdziałania COVID-19 (Dz.U. z 2020 r., poz. 790).

${ }^{75}$ A szülői felügyelet hiányát okozhatja igazolt vagy feltételezett fertőzés, kórházi ellátás vagy házi elkülönítés.

${ }^{76}$ A kínai kormány közleménye, 2020. 03. 15. http://www.gov.cn/xinwen/2020-03/15/content_5491583.htm (2020. 03. 30.).

77 Az új koronavírus-járvány következményeként a gondozást nélkülöző gyermekek támogatásáról és védelméről szóló munkaterv, 2020. 03. 15. Lásd a kínai kormányzati portálon: http://www.gov.cn/zhengce/content/2020-03/15/content_5491581.htm (2020. 03. 30.).

${ }^{78}$ A kínai kormány idézett közleménye, 2020. 03. 15.
} 
Japánban a kormány személyenként és naponta 8.330 jen összegủ segélyt nyújtott azoknak a vállalkozásoknak, amelyekben a szülök fizetett szabadságot vettek ki gyermekgondozási célból. ${ }^{79}$

A fentiek alapján látható, hogy lényeges részét képezte az állami intézkedéseknek a járvány idején a gyermekgondozás kérdése. Az intézkedések célja miatt a hasonlóságok is számosak, és ezeket többnyire a létező társadalombiztosítási rendszerre építették rá.

\section{A feltétel nélküli alapjövedelemhez hasonlító segélyek}

A universal basic income, vagy feltétel nélküli alapjövedelem (a továbbiakban UBI), nem újkeletű ötlet, már korábban is megfogalmazásra kerültek erre vonatkozó gondolatok ${ }^{80}$ Számos kísérleti projektben próbálták ki a gyakorlati megvalósítását, melyek lényeges tapasztalatokat nyújtottak a további kivitelezéshez. A fentiekben bemutattuk, hogy a kormányzat több államban részt vállalt a munkavállalók bérének megfizetésében, ezeket az intézkedéseket azonban nem szabad összetéveszteni az UBI-val. Az UBI ugyanis alapvetően közvetlen és feltétel nélküli rendszerben nyújt alapjövedelmet minden állampolgár számára.

Az új koronavírus miatti krízishelyzetben érdemes megfigyelni, hogy milyen lehetőségeket tud nyújtani az UBI a negatív munkaerőpiaci hatások kezelésében. Az UBI-ról több olyan vélemény fogalmazódott meg, amelyek szerint jó megoldást jelenthet a járvány társadalmi-gazdasági hatásainak enyhítésére. ${ }^{81}$ Könnyü belátni, hogy a szegényebb rétegeket súlyosabban érinti a járvány, ezért egy UBI típusú intézkedés elfogadása lényeges támaszt jelenthet számukra. Implementálása szempontjából számos megoldás javaslat létezik, Standing például inkább a feltétel nélküli rendszert tartja igazán célravezetőnek. ${ }^{82}$ Általánosságban megállapíthatjuk, hogy minden esetben az államok belső helyzetére kell tekintettel lenni, és annak viszonylatában kell a támogatási rendszert felállítani. Az UBI semmi esetre sem egy csodaszer, amellyel minden társadalmi és egészségügyi gondot le lehet győzni. Egy ilyen típusú politika implementálásának céljai a járvány idején leginkább a bizonytalanság csökkentése és a megélhetés javítása kell, hogy legyenek. Ilyen értelemben az ENSZ Fejlesztési Programja is ajánlja, a jelenlegi járványhelyzetre tekintettel,

\footnotetext{
${ }^{79}$ Sajtóhír, Basic Income Today, 2020. 03. 09. https://basicincometoday.com/in-response-to-covid-19-japan-isgoing-to-start-paying-parents-80-a-day-to-stay-home-from-work-and-take-care-of-their-kids/ (2020. 09. 18.).

${ }^{80}$ Kiemelkedik e téren: Van Parijs, Philippe (ed.): Arguing for Basic Income - Ethical Foundations for a Radical Reform. Verso, New York-London, 1992. Újabb szakirodalom: StAnding, Guy: Basic Income: And How We Can Make It Happen. Penguin Random House UK, 2017; Van Parijs, Philippe (ed.): Basic Income and the Left - A European Debate. Social Europe Edition, 2018; VAN PARIJS, Philippe, VANDERBORght, Yannick: Basic Income. Harvard University Press, Cambridge Massachusetts, London, 2017. A koncepció lényegéröl és a kísérleti projektekröl lásd Arnold, Carrie: Money for nothing: the truth about universal basic income. Nature News Feature, 30. May 2018. https://www.nature.com/articles/d41586-018-05259-x (2020. 09. 18.).

81 Standing, Guy: Coronavirus has shown us why we urgently need to make a basic income a reality. World Economic Forum, 13 Apr 2020. https://www.weforum.org/agenda/2020/04/coronavirus-made-basic-incomevital/ (2020. 09. 18.).

${ }^{82}$ Standing: i. $\mathrm{m}$.
} 
egy meghatározott idöre szóló alapjövedelem bevezetését. ${ }^{83}$ Ebben a kontextusban nem célunk az UBI-val kapcsolatos viták feltárása, vagy az eddigi kísérleti projektek részletes tárgyalása - ezeket meg lehet találni a már említett szakirodalomban. Célunk inkább az UBI-hoz közel álló intézkedések bemutatása, amelyek kimondottan a járvány okozta nehézségekre és bizonytalanságokra szolgálnak válaszul.

A járvány alatt a közvetlen segélyezési rendszerek váltak közpolitikai opciókká többek között Japánban, az USA-ban, Ausztráliában, illetve Spanyolországban. Spanyolországban 2020 júniusában kezdődött el egy program, amellyel mintegy 850.000 háztartás, a legszegényebb családok részesülhettek legfeljebb egy havi 1.015 euró jövedelemben. A programot joggal nevezik az egyik legnagyobb közgazdasági kísérletnek. ${ }^{84} \mathrm{~A}$ kifizetett összeg különböző feltételek mentén változik, például egy egyszemélyes háztartás esetében 462 euróra csökken. Az ekképpen biztosított, feltétel nélküli alapjövedelem célja a spanyol társadalombiztosítási miniszter szerint az alapvető szükségletek ellátása, olyan módon, hogy a program ne ejtse a rászorulókat a szegénység csapdájába, mint ahogy az a szokásos szociális segélyezési programok esetében történik, amelyek kizárólag munka- és jövedelemnélkülieknek szólnak ${ }^{85} \mathrm{~A}$ miniszter szerint a programot a koronavírus miatti fenyegetettség elmúlása után is fenn fogják tartani.

Egy az UBI-hoz hasonló támogatási programot állított fel a Trump-kormány az USA-ban. A több mint két milliárd dolláros gazdaság-élénkítő intézkedési csomag létrehozott egy úgynevezett economic impact payment rendszert, ${ }^{86}$ amelyben az adott évi, meghatározott jövedelmi szint alatt elhelyezkedő személyek jogosultak részt venni. A vonatkozó törvény (Coronavirus Aid, Relief, and Economic Security $A c t$, vagy CARES Act) ilyen módon lehetővé tette egy 1.200 dolláros járadék eljuttatását több mint 100 millió személyhez. ${ }^{87}$

Japánban Shinzo Abe miniszterelnök a veszélyhelyzethez kapcsolódóan egy pénzbeli juttatási programot ${ }^{88}$ is elindított, amelynek keretében egy egyszeri, személyenként 100.000 jen értékủ pénzbeli juttatásban részesülhetett minden japán lakos. ${ }^{89}$

${ }^{83}$ Temporary Basic Income (TBI). Az ENSZ Fejlesztési Programja, 2020. 07. 23. https://www.undp.org/content/ undp/en/home/librarypage/transitions-series/temporary-basic-income--tbi--for-developing-countries.html (2020. 09. 18.).

${ }^{84}$ ARnOLD, Carrie: Pandemic speeds largest test yet of universal basic income. Nature, 2020, 502-503. (doi: 10.1038/d41586-020-01993-3) https://www.nature.com/articles/d41586-020-01993-3 (2020. 09. 18.).

${ }^{85}$ ARNOLD: i. m.

${ }^{86}$ A támogatási rendszer honlapja: https://www.irs.gov/coronavirus/economic-impact-payment-information-center (2020. 09. 18.).

${ }^{87}$ A kincstári ügynökség (U.S. Department of the Treasury) közleménye, 2020. 06. 03. https://home.treasury. gov/news/press-releases/sm1025 (2020. 09. 18.).

88 Japan to give every citizen one-off sum of $¥ 100,000$. Financial Times, 2020. 04. 16. https://www.ft.com/ content/4053e198-437e-4ae5-aab5-fa0ab05f3fa3 (2020. 09. 18.).

${ }^{89}$ Müller, Aline: Cash handouts in Japan: How the financial incentive offered to the whole population in Japan compares to Basic Income. Basic Income Earth Network, May 18, 2020. https://basicincome.org/ news/2020/05/cash-handouts-in-japan-how-the-financial-incentive-offered-to-the-whole-population-in-japancompares-to-basic-income/ (2020. 09. 18.). 
A fentiekben röviden bemutatott, UBI-típusú intézkedések persze messze állnak az ideális UBI-tól, viszont lényeges elörelépést jelentenek. Amerika és Japán esetében egyszeri kifizetésekről beszélünk, nem havi rendszerességű juttatásról, ami alapvetően elkülöníti az UBI-tól, viszont tanulságokkal szolgálhat egy, az eredetihez közelebb álló rendszer bevezetéséhez. Spanyolország esetében egy kvázi-univerzális rendszerről van szó, amelyben a szegények a kedvezményezettek. Valójában a spanyol rendszer az, amely a legtöbb tanulságul szolgálhat egy tényleges UBI típusú rendszer kialakításakor. Hasonló intézkedések bevezetését Dél-Koreában is tervezik. ${ }^{90}$

\section{Egyéb intézkedések}

Több olyan megoldással is találkoztunk kutatásunk során, amely egyik, eddig ismertetett támogatási csoportba sem tartozik, azonban a veszélyhelyzet miatti intézkedések körében szociális és foglalkoztatási jelentőséggel bír, így ezeket is érdemesnek tartottuk a bemutatásra.

Svájcban a Szövetségi Tanács 280 millió svájci frankot fordított az ország kulturális életének megőrzésére. A támogatás célja a különböző rendezvények elmaradásából származó bevételkiesések kompenzálása volt; a jogosulti körbe ezért az előadóművészek, a tervezők, a mozik, a vizuális művészek, az irodalmi alkotók, a zenészek és a múzeumok tartoztak. Két hónapos időszak alatt szövetségi szinten megvizsgálták a kantonok és kulturális szervezetek helyzetének megváltozását. Az elöirányzott lépések közé tartozik, hogy a Szövetség azonnali segítségnyújtást tesz lehetővé a kulturális szereplők számára. A kompenzáció a kár legfeljebb $80 \%$-át fedezi, és a kantonok által megítélt juttatás felét a Szövetség biztosítja. ${ }^{91}$ Ezen túlmenően, mivel a járványügyi intézkedések miatt számos sporteseményt is törölni kellett, a sportklubok és egyesületek túlélése és a svájci sportstruktúra megóvása érdekében a Szövetségi Tanács 50 millió svájci frank visszatérítendő támogatást biztosított a profi egyesületek számára, és ugyanekkora összeget juttat a tömegsportokat összefogó szervezetek számára is. ${ }^{92}$

Lengyelországban a 2020. április 16-án elfogadott, úgynevezett „második válságelhárító pajzs" törlesztési moratóriumot vezetett be a diákhitelek vonatkozásában. A moratórium a 2019-2020-as egyetemi tanév végéig tartott, a törlesztés felfüggesztését legfeljebb 6 hónapra lehetett kérelmezni. ${ }^{93} \mathrm{~A}$ diákhitel-adósság vonatkozásában az Amerikai Egyesült Államokban is született intézkedés, amely lehetővé tette, hogy a diákhitel törlesztését három hónapra felfüggesszék, amely további három hónappal volt meghosszabbítható. ${ }^{94}$

90 Dongwoo, Kim: South Korea Mulls Universal Basic Income Post-COVID. The Diplomat, 2020. 06. 13. https:// thediplomat.com/2020/06/south-korea-mulls-universal-basic-income-post-covid/ (2020. 09. 18.).

91 A Svájci Szövetségi Tanács sajtóközleménye, 2020. 03. 20. www.admin.ch/gov/fr/accueil/documentation/ communiques.msg-id-78515.html (2020. 09. 18.).

92 A Svájci Szövetségi Tanács idézett sajtóközleménye, 2020. 03. 20.

${ }^{93}$ Ustawa z dnia 16 kwietnia 2020 r. o szczególnych instrumentach wsparcia w związku z rozprzestrzenianiem się wirusa SARS-CoV-2, 79. Art. (2).

${ }^{94}$ Coronavirus Aid, Relief, and Economic Security Act (CARES Act), Section 4513, (a), (d). 
Csehországban kilakoltatási tilalmat vezettek be azon személyek esetében, akik a koronavírus-járvány okozta gazdasági nehézségek következtében nem tudták lakbérüket fizetni. ${ }^{95}$ Emellett az ipari és kereskedelmi miniszter április 16-án jelentette be azt a legújabb pályázati programot, amely az újitásokról szólt. A pályázatokat 2020. december 31-ig lehetett benyújtani. A pályázat célja, hogy a kommunikáció fejlesztését, valamint a tudásmegosztást támogassa a kutatók és az üzleti vállalkozások között, annak érdekében, hogy legyőzzék a koronavírust. A program teljes tervezett költségvetése 50 millió cseh korona. ${ }^{96}$

Olaszországban a munkáltatók számára juttatásokat biztosítottak a munkakörnyezet és a munkaeszközök tisztításával (fertőtlenítésével) kapcsolatban felmerülö költségeikre: azok 50\%-ának megtérítésére, de nem több mint 20.000 euróra számíthattak. Az üzletek és üzemek bérleti díjának 60\%-át megtérítette az állam 2020. március hónapra. Kivételt képeznek azok a vállalkozások, amelyeknek sikerült folytatni tevékenységüket a korlátozások ellenére. ${ }^{97}$

Spanyolországban királyi rendelettel garantálták a villamosenergia-, a földgáz-, és a vízellátást, valamint az elektronikus és a telefonos kommunikáció fenntartását azon fogyasztók számára, akik az úgynevezett sérülékeny fogyasztók csoportjába tartoznak..$^{98}$

A különböző adók és járulékok, valamint a hiteltörlesztö-részletek megfizetésének kötelezettségét számos országban elhalasztották. Csehországban a 2020. március 26. elött kötött kölcsönszerződések visszafizetését 6 hónapra felfüggesztették. A halasztás nem automatikus, az adósnak értesítenie kell a hitelezőt, hogy a járványhelyzet miatt átmenetileg nem képes a törlesztő részleteket fizetni. ${ }^{99}$

\section{Zárógondolatok}

A koronavírus terjedését megfékező egészségügyi intézkedések bizonyos mértékben mindenkire gazdasági hatással voltak. A fentiekben felvonultatott rendkívüli megoldások az államok elképesztő méreteket öltő beavatkozási kényszeréröl tanúskodnak. Az intézkedések elsődleges célja egyértelmüen az egészségügyi helyzet fölötti kontroll, a negatív gazdasági következmények elkerülésével és enyhítésével egyetemben. A szociális távolságtartásból származó negatív, főként gazdasági, de egyéb következmények ellensúlyozására elfogadott szerteágazó és innovatív intézkedések által sikerült a járvány elején elkerülni egy mélyebb válságot.

A pandémia kontextusában kérdés marad, hogy az intézkedések milyen mértékben és meddig tarthatók fenn, illetve, hogy az innovatívabb intézkedések megfelelő eredményeket fognak-e elérni vagy sem. Pozitívumként, Winston Churchill híres

\footnotetext{
${ }^{95}$ A cseh területfejlesztési tárca közleménye, 2020. 04. 01.https://mmr.cz/cs/ostatni/web/novinky/najemnikumje-treba-v-nouzovem-stavu-rozhodne-pom (2020. 09. 18.).

96 Osinová, Karin-Kadeřábková, Renata: Novinky v dotacích v souvislosti s COVID-19. KPMG Daňové a právní aktuality, 21. 4. 2020. https://danovky.cz/cs/novinky-v-dotacich-v-souvislosti-s-covid-19 (2020. 09. 18.).

97 Decreto-Legge 17 marzo 2020, n. 18, Articolo 23, 8.

98 A 2020/8. törvényerejü rendelet angol nyelvű kivonata.

${ }^{99}$ A cseh pénzügyminisztérium közleménye, 2020. 04. 10. https://www.mfcr.cz/cs/aktualne/tiskove-zpravy/2020/ vlada-schvalila-moratorium-na-splatky-uv-38077 (2020. 09. 18.).
} 
gondolatára („never let a good crisis go to waste”) utalva úgy gondoljuk, hogy jelen helyzet a kormányok számára megfelelő környezetet teremtett olyan intézkedések kipróbálására, amelyek ezidáig túl radikálisnak tủnhettek. A járvány ideje alatt végbement, kényszerủ digitalizáció az adaptációs képességeinket igazolja, viszont fontos, hogy e mellé komoly és a jövőt szem előtt tartó társadalombiztosítási intézkedések is társuljanak, amelyek a digitális flexibilitást kiegészítik, és az automatizálás következményeit már most kompenzálják. 